実験・技術・調査報告・Report

\title{
低火度焼成磁器の開発研究
}

\author{
今井寛治・磯松良純・浅見 董 \\ (京都市工業試験場)
}

\begin{abstract}
磁器素地の通常の焼成は $1300^{\circ} \mathrm{C}$ という高温であるため大量のエネルギ一を必要とする．焼成の エネルギーを節減するため磁器の特性を変えないで $1100^{\circ} \mathrm{C}$ という低温で焼成できる素地を開発

し，その磁器化過程，素地特性を明らかにした。

この素地の組成式は $0.40 \mathrm{KNaO} ・ 0.16 \mathrm{CaO} \cdot 0.21 \mathrm{MgO} \cdot 1.00 \mathrm{Al}_{2} \mathrm{O}_{3} \cdot 6.99 \mathrm{SiO}_{2} \cdot 0.10 \mathrm{~B}_{2} \mathrm{O}_{3}$ で 示される。この素地は $\mathrm{B}_{2} \mathrm{O}_{3}$ 系フリット, アルカリ, アルカリ土類成分を添加しているが, 安定し た磁器化状態を保ち鉱物組成, 素地特性等も従来の磁器と大差ない。また陶石合わせ素地のため可 塑性もあり，これまでの生産工程を変更することなく製造することが可能である.
\end{abstract}

実験炉では，焼成時間が約 $30 \% ，$ 燃料が 30 40\% 節減できることが確認された。

(1983 年 6 月 13 日受付)

\section{Development on the Porcelain Body of the Lower Firing Temperature}

\author{
Kanzi IMAI, Yoshizumi ISOMATSU and Kaoru ASAMI \\ $\left(\begin{array}{ll}\text { Kyoto Municipal Institute of Industrial Research } & \\ 1-2, \text { Nanden-cho, Nishikujo, Minami-ku, Kyoto-shi } & 601\end{array}\right)$
}

\begin{abstract}
A large amount of thermal energy is required for the firing of porcelain wares which is generally carried out at a temperature as high as $1300^{\circ} \mathrm{C}$. In order to minimize energy required in the firing of porcelain, we developed a new composition which could be fired at a lower temperature of $1100^{\circ} \mathrm{C}$ without losing its porcelain properties, and its characteristics such as the vitrification behavior were investigated. The composition of the body was expressed as 0.40 $\mathrm{KNaO} \cdot 0.16 \mathrm{CaO} \cdot 0.21 \mathrm{MgO} \cdot 1.00 \mathrm{Al}_{2} \mathrm{O}_{3} \cdot 6.99 \mathrm{SiO}_{2} \cdot 0.10 \mathrm{~B}_{2} \mathrm{O}_{3}$ by the Seger formula. Although the body contained $\mathrm{B}_{2} \mathrm{O}_{3}$-frit, alkali and alkaline earth metals as additives, a stable vitrification process of the body was maintained, and no difference could be observed in the mineral composition and physical characteristics of the porcelain prepared from the body and the typical vitrified porcelains prepared by the conventional method. This green body is based upon pottery stone (Toseki) which possesses plasticity, therefore, no modification of the conventional process is necessary in molding the body. An experiment carried out using an experimental kiln (internal volume of about $0.5 \mathrm{~m}^{3}$ ) showed that reductions in the firing time of about $30 \%$ and in the fuel consumption of $30 \sim 40 \%$ are obtained as compared with the firing of a body containing no additive.

[Received June 13, 1983]
\end{abstract}

Key-words : Porcelain body, Lower firing, Additives, Stable vitrification process, Physical characteristics

\section{1. 緒言}

石油系燃料の高騰から窯業のようなエネルギー多量消 費型産業ではそのための製造原価が急激に上昇し厳しい 環境におかれている。このような現状から多種多様な省 エネルギーに関する研究と対策が実施されている. 焼成 のためのエネルギー節減のためには, $(1)$ 窟の構造と操 炉法の改善, 例えば迅速焼成法1等, ( 2 ) 素地の化学組 成の改善による焼成温度の低温化等の方法がある.
低火度焼成素地の開発は夕イル素地では数多く行わ れ，例えばパーライト，ネフェリンサイアナイトを添加 した素地 ${ }^{21}$ ，抗火石一ガラス-粘土系で $1050^{\circ} \mathrm{C}$ で焼成で きる素地 ${ }^{31}$ ，ガラスータルクーベントナイト系で $1000^{\circ} \mathrm{C}$ で焼成できる素地等がある．磁器素地では灰長石質原 料を用いたもの $0^{51}$ ，リン酸成分を添加したもの ${ }^{61}$ な゙が ある。また天草陶石のこれまであまり利用されていない アルカリ陶石を用い $1280^{\circ} \mathrm{C}$ で焼成可能な素地 ${ }^{71}$ や粘土一 
長石一石英-ケイ長石系で従来の美濃焼磁器の焼成温度を $100^{\circ} \mathrm{C}$ 低くできる素地 ${ }^{8}$ 等も開発されている.

本研究は先の磁器素地より更に低い $1100^{\circ} \mathrm{C}$ 程度で焼 成可能で，かつ現在の市販磁器素地同様陶石立て調合で 成形性のある新しい低火度焼成磁器素地の開発を行っ た.

\section{2. 実験}

\section{1 試料作製}

磁器素地の調合は陶石, 長石, 粘土, 石英等を三角座 標で配合する方法が一般的であるが，本研究ではゼーゲ ル組成式を活用し素地調合を行った.

試料は素地乾粉に $1 \%$ カルボキシメチルセルロース 溶液を噴霧加水した後造粒し, それを $350 \mathrm{~kg} / \mathrm{cm}^{2}$ で加 圧成形し $40 \mathrm{~mm} \phi$ の円板とした。焼成は電気炬により $65^{\circ} \mathrm{C} / \mathrm{h}$ で昇温し, 所定温度で 30 分保持した後炉冷した。

\section{2 焼成体の評価方法}

素地の磁器化過程を検討する場合，単に磁器化温度た けで評価するのは不完全であり, 素地組成により焼成後 の鉱物組成, 液相の組成, 量, 粘度等に差が生じ, 焼成幅, 磁器化状態は非常に異なってくる. 本研究は Norris ${ }^{9)} の$ 方法に準じ, 焼成温度の異なる試料で焼成収縮率, 吸水

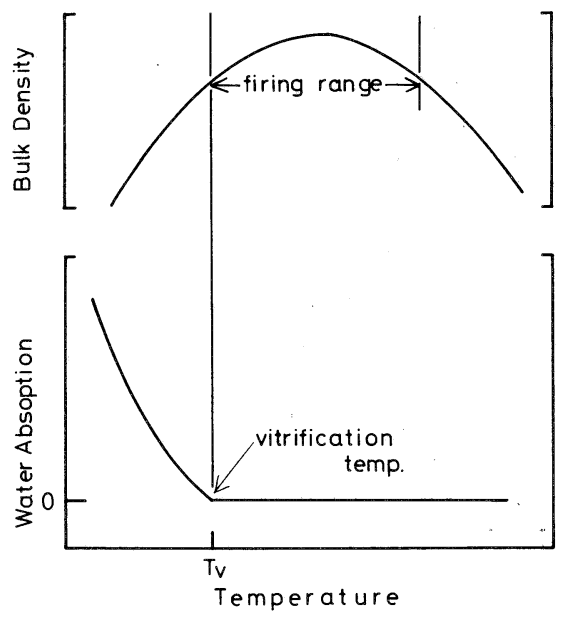

Fig. 1. Determination of vitrification temperature and firing range.
率, かさ比重曲線を求め, 吸水率が 0 となる温度を磁器 化温度 $T_{\mathrm{v}}$, かさ比重曲線で $T_{\mathrm{v}}$ 温度のかさ比重值と再 交差する温度との差を焼成幅 $T_{\mathrm{w}}$ とした。この決定法の 模式図を図 1 に示す．またガラス相の多い素地では素地 が急激に焼きしまるが，その磁器化過程を見るため焼成 収縮率曲線において磁器化が進行するとき（ $T_{\mathrm{v}}$ よりや や低い温度）の焼成収縮率曲線の傾き $G$ を求めた。ゆ るやかに磁器化するときはこの值は小さく, 急激に磁器 化するときは大きくなる．この $T_{\mathrm{v}}, T_{\mathrm{w}}, G$ の值により 素地の磁器化状態の差異を判定した。

また素地焼成物について，粉末 X 線回折により生成 鉱物相，量についても検討した。

\section{3. 結果と考察}

\section{1 融剂，石灰，マグネシア成分の焼結効果}

素地の焼成温度を下げる場合, 融剂として㗢くガラス フラックス ${ }^{3), 4), 10 \mid}$ や長石，ネフェリンサイアナイトなど のアルカリ成分, タルク, ワラストナイト,アノーサイト, リン酸カルシウムなどのアルカリ土類成分 ${ }^{61,11), 12)}$ を添加 することにより達成できる。

添加融剂について, 予備試験として表 1 に示す融剤を 高温顕微鏡観察，素地配合試験を行った結果，素地への 着色や素地の発泡, 溶融現象等が見られ，これらの中で F 1 フリットを用いれば安定な磁器化状態が得られる と思われた。そこでフリット成分についてはF 1 フリッ ト，アルカリ土類成分は石灰，マグネシアを素地中に添 加したときの磁器化状態について検討を加えた。

実験は業界で使用している一般的な磁器坏土 ${ }^{13)}$ (上石 坏土，Jと表示）にF 1 フリット $5 \mathrm{wt} \%$ ( J 1 ), $10 \mathrm{wt} \%$ ( J 2 )，また同素地 $1 \mathrm{~mol}$ に対し石灰石 $1 \mathrm{~mol} \mathrm{(JC),}$ マグネサイト $1 \mathrm{~mol}(\mathrm{JM})$, 石灰石 $0.5 \mathrm{~mol}$ とマグネサ イト $0.5 \mathrm{~mol}(\mathrm{JCM})$ をそれぞれ添加した素地の焼結挙 動について調べた。

添加素地の焼成収縮率, 吸水率測定の結果の一部を図 2 ( J 1, JC, JM) に, 磁器化特性值を表 2 に示す.

$\mathrm{B}_{2} \mathrm{O}_{3}$ 系フリットは融剤としての効果は大きく， $5 \%$ 添加したとき $95^{\circ} \mathrm{C}, 10 \%$ 添加で $130^{\circ} \mathrm{C}$ 磁器化温度は低 下する．フリット添加量が多くなるほど焼成幅は狭くな

Table 1. Chemical composition of fluxes (wt \%).

\begin{tabular}{|c|c|c|c|c|c|c|c|c|c|}
\hline & $\mathrm{SiO}_{2}$ & $\mathrm{Al}_{2} \mathrm{O}_{3}$ & $\mathrm{Fe}_{2} \mathrm{O}_{3}$ & $\mathrm{MgO}$ & $\mathrm{CaO}$ & $\mathrm{K}_{2} \mathrm{O}$ & $\mathrm{Na}_{2} \mathrm{O}$ & $\mathrm{B}_{2} \mathrm{O}_{3}$ & Ig.Loss \\
\hline Glass Powder & 68.70 & 2.35 & 0.05 & 1.71 & 8.46 & 1.22 & 16.69 & - & 0.70 \\
\hline Shirasu & - & - & - & - & - & - & - & - & - \\
\hline Kokaseki & 77.0 & 11.0 & 1.6 & 0.4 & 1.0 & 8.6 & & - & - \\
\hline Frit $\quad F-1$ & 46.52 & 0.94 & tr & 0.26 & 11.36 & 0.03 & 11.95 & 26.70 & $\operatorname{tr}$ \\
\hline Frit & 39.84 & 17.25 & 0.04 & 0.03 & 0.44 & 4.08 & 12.64 & 25.33 & tr \\
\hline Frit & 44.95 & 3.62 & 0.10 & 0.48 & 10.60 & 2.14 & 11.04 & 26.73 & $\operatorname{tr}$ \\
\hline $\begin{array}{l}\text { Fukushima } \\
\text { Choseki }\end{array}$ & 65.07 & 18.78 & 0.18 & 0.15 & 0.34 & 12.30 & 3.15 & - & 0.31 \\
\hline Calcium Pho & hate & drate & $(G . R)$. & & $\mathrm{H}_{4}($ & ${ }_{2} \mathrm{H}_{2} \mathrm{O}$ & & & \\
\hline
\end{tabular}




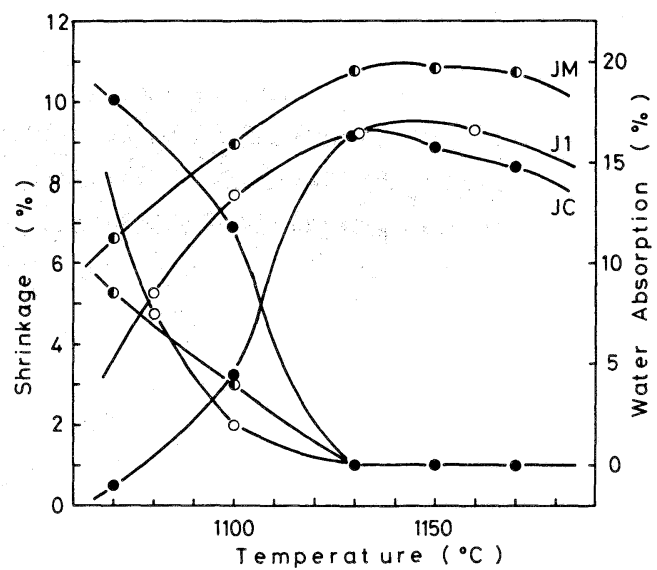

Fig. 2. Effect of addition of flux, lime and magnesia components on sintering.

Table 2. Vitrification characteristic of addition of flux, lime and magnesia.

\begin{tabular}{lccc}
\hline & TV & Tw & G \\
\hline J & 1230 & 40 & 0.03 \\
J1 & 1135 & 35 & 0.06 \\
J2 & 1100 & 30 & 0.10 \\
JC & 1130 & 15 & 0.30 \\
JM & 1130 & 35 & 0.10 \\
JCM & 1130 & 20 & 0.25 \\
\hline
\end{tabular}

り磁器化の進行も早くなる．フリット $10 \%$ 添加したも のはアノーサイトが生成する，石灰·(JC), 石灰とマグ ネサイト（JCM）を添加した素地は同様な傾向を示し $1100^{\circ} \mathrm{C}$ から急激に磁器化し，焼成幅も石灰石が多いほ ビ狭くなり溶化傾向を示す。マグネサイト（JM）を添 加したものはゆっくりと磁器化し焼成幅も広いが, 焼成 後の素地呈色が黄色味を帯び透光性も悪くなる傾向にあ
る.

\section{2 素地調 合}

使用原料の化学分析値之X 線回折による鉱物組成を 表 3 , 表 4 に示す。陶石については種々の陶石の試験 ${ }^{14)}$ を行った結果トスダイト(アルミニウム質緑泥石-モン モリロナイト混合層粘土）を多く含み可塑性に富む上尾

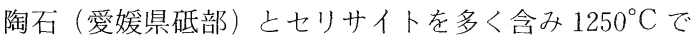
磁器化する清見陶石（岐阜県清見）を用いた。

調合は( 1 )式の組成範囲で行った。

$$
\begin{array}{l|l}
0.28 \sim 0.72 \mathrm{KNaO} & \\
0.16 \sim 0.94 \mathrm{CaO} & 1.00 \mathrm{Al}_{2} \mathrm{O}_{3} \cdot 6.99 \sim 7.68 \\
0.21 \sim 0.67 \mathrm{MgO} & \mathrm{SiO}_{2} \cdot 0.11 \mathrm{~B}_{2} \mathrm{O}_{3}
\end{array}
$$

$\mathrm{A} \sim \mathrm{K}$ 調合の素地組成を表 5 に示す。素地に可塑性を増 すため蛙目粘土 $10 \% ， 3.1$ 節の結果より融剤として F 1 フリット $5 \%$ 添加している.

焼成収縮率, 吸水率测定の結果の一部を図 3 (A, G, K 素地) に磁器化特性值を表 6 に示す。この組 成範囲で磁器化温度は $1075^{\circ} \sim 1115^{\circ} \mathrm{C}$, 焼成幅は $15^{\circ} \sim$ $30^{\circ} \mathrm{C}$ である. A, H, I, K 素地は焼成幅 $T_{\mathrm{w}}$ が広く $G$ 値も 小さく安定した磁器化状態を示す。この結果より

1）アルカリ，アルカリ土類成分を多くするほど磁器 化温度は低下し焼成幅も狭くなり，素地は急激に焼きし まり溶化しやすくなる。

2) $\mathrm{CaO} / \mathrm{MgO}$ 比が大きい方が磁器化は急激となり 溶化しやすくなる傾向を示し, $\mathrm{CaO}$ 成分は融剤として の効果が大きい.

3) $\mathrm{SiO}_{2} / \mathrm{Al}_{2} \mathrm{O}_{3}$ 比が小さい方が磁器化温度は上昇し, 焼成幅は広くなり最大かさ比重も高くなる。

4）素地調合においてアルカリ成分を多くすると長 石，ケイ石量が増加し可塑性原料（陶石，カオリン）が 少なくなる，成形性を考虑する場合には可塑原料が多い

\begin{tabular}{|c|c|c|c|c|c|c|c|c|c|}
\hline & $\mathrm{SiO}_{2}$ & $\mathrm{Al}_{2} \mathrm{O}_{3}$ & $\mathrm{Fe}_{2} \mathrm{O}_{3}$ & $\mathrm{MgO}$ & $\mathrm{CaO}$ & $\mathrm{K}_{2} \mathrm{O}$ & $\mathrm{Na}_{2} \mathrm{O}$ & $\mathrm{TiO}_{2}$ & Ig. LOSE \\
\hline $\begin{aligned} & \text { Kiomi Toseki } \\
&(1\text { Class })\end{aligned}$ & 77.38 & 14.58 & 0.46 & 0.26 & 0.31 & 3.88 & 1.08 & - & 2.07 \\
\hline $\begin{array}{l}\text { Uebi Toseki } \\
\qquad \begin{array}{r}1 \text { Class })\end{array}\end{array}$ & 78.88 & 14.77 & 0.22 & 0.12 & 0.22 & 0.68 & 0.16 & - & 4.69 \\
\hline $\begin{array}{l}\text { Fukushima } \\
\text { Choseki }\end{array}$ & 65.07 & 18.78 & 0.18 & 0.15 & 0.34 & 12.30 & 3.15 & - & 0.31 \\
\hline Kato Kaolin & 45.75 & 37.23 & 0.62 & 0.33 & 1.60 & 0.54 & 0.57 & 0.11 & 12.86 \\
\hline Keiseki & 98.92 & 0.06 & 0.41 & - & - & - & - & - & 0.06 \\
\hline Dolomite & 0.41 & 0.73 & 0.20 & 17.53 & 35.33 & $\operatorname{tr}$ & 0.03 & - & 45.48 \\
\hline Calcite & 0.24 & 0.25 & 0.15 & 1.21 & 54.67 & 0.01 & 0.31 & - & 42.83 \\
\hline Magnesite & 2.22 & 0.56 & 0.53 & 46.12 & 0.67 & 0.02 & 0.04 & - & 49.81 \\
\hline $\begin{array}{r}\text { Shinmurakami } \\
\text { Clay }\end{array}$ & 74.10 & 16.76 & 0.44 & 1.12 & 0.19 & 3.27 & 0.71 & 0.11 & 3.56 \\
\hline $\begin{array}{l}\text { Tokiguchi } \\
\text { Gairome }\end{array}$ & 48.52 & 34.05 & 1.92 & 0.16 & 0.90 & 1.75 & 0.17 & 0.84 & 11.89 \\
\hline
\end{tabular}

Table 3. Chemical composition of raw materials (wt\%). 
Table 4. Mineral composition of raw materials.

\begin{tabular}{ll}
\hline & \multicolumn{2}{c}{ Minerals } \\
\hline Kiomi Toseki & Quartz Kaolinite Sericite \\
Uebi Toseki & Quartz Kaolinite Tosudite \\
Fukushima Choseki & Orthoclase Quartz \\
Kato Kaolin & Halloysite Anorthite \\
Keiseki & Quartz \\
Dolomite & Dolomite Calcite \\
Calcite & Calcite Dolomite \\
Magnesite & Magnesite Zincite Dolomite Talc \\
Shinmurakami Clay & Quartz Sericite Kaolinite \\
Tokiguchi Gairome & Kaolinite Quartz \\
\hline
\end{tabular}

Table 5. Chemical composition of the bodies ( $\mathrm{mol}$ ).

\begin{tabular}{ccccccc}
\hline & $\mathrm{KNaO}$ & $\mathrm{CaO}$ & $\mathrm{MgO}$ & $\mathrm{Al}_{2} \mathrm{O}_{3}$ & $\mathrm{SiO}_{2}$ & $\mathrm{~B}_{2} \mathrm{O}_{3}$ \\
\hline $\mathrm{A}$ & 0.28 & 0.90 & 0.41 & 1.00 & 7.64 & 0.11 \\
$\mathrm{~B}$ & 0.43 & 0.79 & 0.37 & 1.00 & 7.63 & 0.11 \\
$\mathrm{C}$ & 0.57 & 0.68 & 0.32 & 1.00 & 7.63 & 0.11 \\
$\mathrm{D}$ & 0.72 & 0.60 & 0.26 & 1.00 & 7.63 & 0.11 \\
$\mathrm{E}$ & 0.43 & 0.56 & 0.67 & 1.00 & 7.68 & 0.11 \\
$\mathrm{~F}$ & 0.43 & 0.65 & 0.52 & 1.00 & 7.68 & 0.11 \\
$\mathrm{G}$ & 0.43 & 0.94 & 0.22 & 1.00 & 7.68 & 0.11 \\
$\mathrm{H}$ & 0.46 & 0.26 & 0.21 & 1.00 & 7.54 & 0.11 \\
$\mathrm{I}$ & 0.46 & 0.18 & 0.29 & 1.00 & 7.54 & 0.11 \\
$\mathrm{~K}$ & 0.40 & 0.16 & 0.21 & 1.00 & 6.99 & 0.11 \\
\hline
\end{tabular}

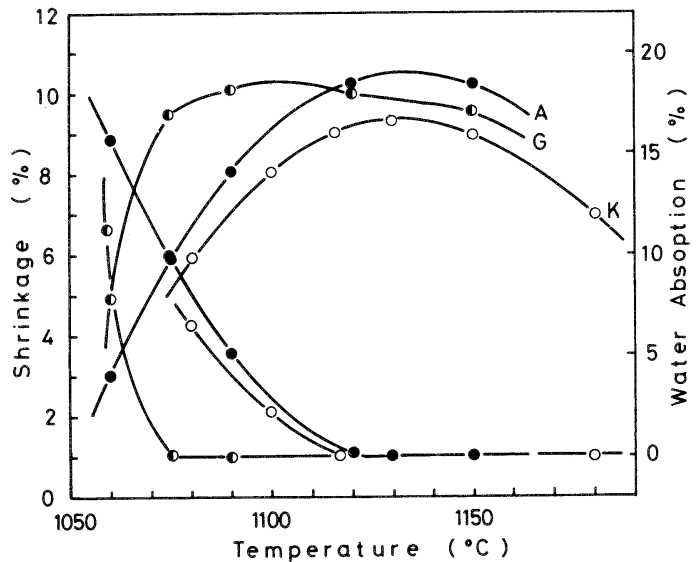

Fig. 3. Vitrification process of the bodies $A, G$ and $K$.

方が望ましくアルカリ，アルカリ土類成分は $0.4 \sim 0.5$ $\mathrm{mol}$ が適当である。

\section{3 鉱物組成と磁器化状態}

石灰質磁器については灭長石質原料を用いた磁器の報 告 ${ }^{5)}$ や村らが $\mathrm{CaO}-\mathrm{Al}_{2} \mathrm{O}_{3}-\mathrm{SiO}_{2} 3$ 成分系組成範囲でち 密化過程, 鉱物組成, 微構造の変化について詳細に検討 ${ }^{151}$ したものがある. 本実験のように石灰成分以外にアルカ リ成分やフリットを添加した複雑な系についてはこれま
Table 6. Vitrification characteristics of the bodies A-K.

\begin{tabular}{cccc}
\hline & TV & Tw & G \\
\hline A & 1120 & 30 & 0.14 \\
B & 1095 & 25 & 0.22 \\
C & 1075 & 25 & 0.33 \\
D & 1075 & 15 & 0.31 \\
E & 1090 & 30 & 0.23 \\
F & 1090 & 30 & 0.23 \\
G & 1080 & 30 & 0.32 \\
H & 1085 & 35 & 0.13 \\
I & 1080 & 30 & 0.13 \\
K & 1115 & 30 & 0.10 \\
\hline
\end{tabular}

Table 7. Presence of minerals in the fired bodies.

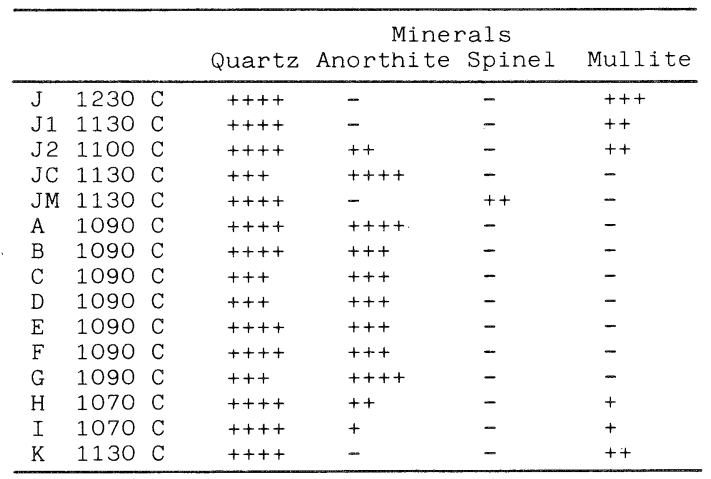

で報告がなく, 磁器化状態と鉱物組成, 結晶量の関係に ついて検討した。

素地焼成物について，粉末 X 線回折により生成鉱物 相の同定を行い，更に残留石英については結晶量の変化 を測定した。測定は石英の $d=3.343 \AA$ の回折ピークを 用い, 半価幅と高さの積により比較し, 素地の磁器化後 の焼成温度と相対量の関係について調べた。

素地焼成物の鉱物組成を表 7 に示す.市販磁器素地 $(J)$ 
焼成物の鉱物組成は残留石英, ムライトよりなる.フリッ トを添加すると融剤としての効果は大きく $1100^{\circ} \mathrm{C} く ら$ いで長石はすべてがラス化しており，石灰成分の多い素 地ではアノーサイトが生成し，ムライトは認められない。 石灰成分の少ない $J, K$ 素地ではアノ一サイトは生成せ す， $\mathrm{H}$ 素地では生成している。これらの素地中の $\mathrm{CaO}$ 量は各々 $0.5 \mathrm{wt} \%, 0.6 \mathrm{wt} \%, 0.8 \mathrm{wt} \%$ であり，本実験

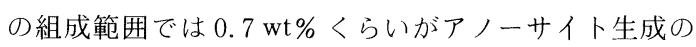
境界亡なるようである. $\mathrm{CaO}$ 成分が多い組成ではアノ一 サイトが多く生成し，残留石英量の減少が著しい。

焼成温度の変化による固相の安定性を見るため磁器化 後の残留石英の変化を調べた. 結果を図 4 に示す.この 図は各素地の磁器化温度での残留石英量を 100 とし, そ れより高い温度で焼成したとき相対量の変化を示す．市 販磁器素地 $(\mathrm{J})$ は $1230^{\circ} \mathrm{C}$ で磁器化し, その後残留石 英の減少はゆるやかであるが, フリット，アルカリ，ア ルカリ土類成分を添加した素地は残留石英の減少は急激 で, 特にアルカリ, 石灰成分の多い素地ではこの傾向が 著しい。この温度範囲でアノ一サイト量はそれほど減少 していないことから残留石英の減少に伴い融液が多く生 成し素地は急激に溶化してゆく.これはかさ比重測定の 結果を見ても磁器化後かさ比重が急激に低下しているこ とからもガラス化が促進していることが分る．このよう に石灰成分の多い素地では残留石英は急激に減少し磁器 化状態の安定性が悪いことが分る.しかし A 素地のよ
うに石灰成分が多くてもアルカリ成分が少なければ磁器 化状態は安定している。 だからアルカリ成分がある程度 存在し, そこへ石灰成分が導入されると残留石英が減少 し液相が急激に生成され, 磁器化状態を保つことが困難 となる。

アルカリ，石灰成分を少なくした H, I, K 素地はムラ イトが生成する.ムライトは融液中で安定して共存でき るため, 安定した磁器化状態を維持しうると考えられる.

以上のことから安定な磁器化状態を保つには存在する 固相量と融液中での安定性が重要であり残留石英とア ノーサイトを, 融液中で安定なムライトを生成させ，ま た温度変化によるガラス相の増加をできるかぎり少なく することで焼成幅の広い安定した素地を得ることができ る. 石灰成分を $0.6 \%$ まで減らしアルミナ成分を多くし た $\mathrm{K}$ 素地は本実験組成範囲では最も安定した磁器化状 態を保つ. $\mathrm{K}$ 素地の調合を表 8 に示す.

\section{4 釉薬調合}

低火度磁器に適合する光沢透明釉の調製を行った. 市 販磁器釉之同様陶石立て石灰釉, 石灰苦土釉で調製した。 釉薬調合組成範囲を( 2 )式に示す.
$0.28 \sim 0.39 \mathrm{KNaO}$
$\left.\begin{array}{l|l}0.40 \sim 0.65 \mathrm{CaO} \\ 0.01 \sim 0.25 \mathrm{MgO}\end{array}\right\} \begin{aligned} & 0.26 \sim 0.54 \mathrm{Al}_{2} \mathrm{O}_{3} \cdot 2.88 \sim 4.75 \\ & \mathrm{SiO}_{2} \cdot 0.48 \sim 0.11 \mathrm{~B}_{2} \mathrm{O}_{3}\end{aligned}$

試験体は $\mathrm{K}$ 素地を用いて下絵の発色等を見るため市販 D 点須で下絵付けを行った. その結果石灰苦土釉で最

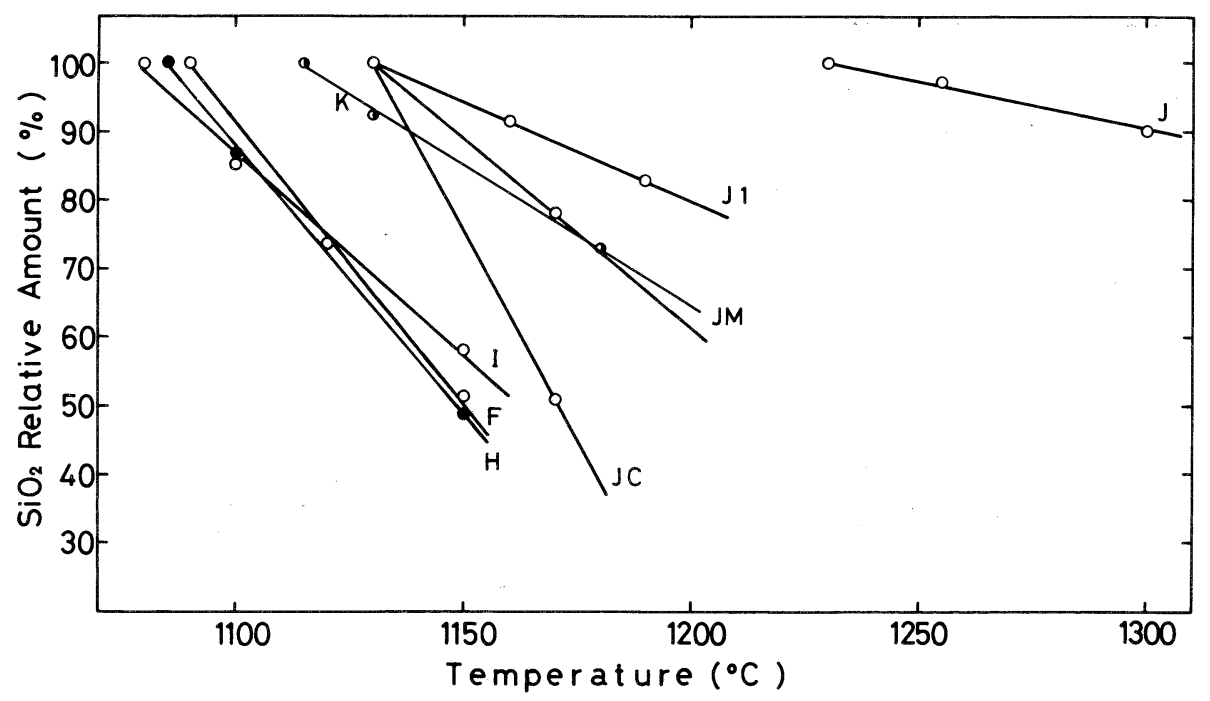

Fig. 4. Variation of the amount of residual quartz after vitrification.

Table 8. Mixing composition of $\mathrm{K}$ body (wt $\%$ ).

\begin{tabular}{|c|c|c|c|c|c|c|c|}
\hline $\begin{array}{l}\text { Kiomi } \\
\text { Toseki }\end{array}$ & $\begin{array}{l}\text { Uebi } \\
\text { Toseki }\end{array}$ & $\begin{array}{l}\text { Murakami } \\
\text { Clay }\end{array}$ & $\begin{array}{l}\text { Fukushima } \\
\text { Choseki } \\
\end{array}$ & $\begin{array}{l}\text { Kato } \\
\text { Kaolin } \\
\end{array}$ & Keiseki & Dolomite & Magnesite \\
\hline 32.91 & 32.91 & 11.62 & 14.64 & 3.23 & 1.22 & 1.48 & 1.99 \\
\hline
\end{tabular}


Table 9. Mixing composition of glaze (wt $\%)$.

\begin{tabular}{llllllllll}
\hline $\begin{array}{l}\text { Kiomi } \\
\text { Toseki Kato Keiseki R. China } \\
(\mathrm{K})\end{array}$ & $\begin{array}{c}\text { Choseki Dolomite Calcite } \\
(\mathrm{Na})\end{array}$ & $\begin{array}{c}\text { out } \mathrm{BaCO}_{3} \\
\mathrm{SrCO}_{3}\end{array}$ & $\mathrm{~F} 1$ & $\mathrm{Frit}$ \\
\hline 39.82 & 9.11 & 18.82 & 5.94 & 13.85 & 9.37 & 3.09 & 3.00 & 3.00 & 20.00 \\
\hline
\end{tabular}

適釉が得られその釉組成及び調合割合を( 3 )式，表 9 に 示す。

$$
\begin{aligned}
& 0.27 \mathrm{KNaO} 0.08 \mathrm{SrO} \\
& \begin{array}{l|l}
0.43 \mathrm{CaO} 0.05 \mathrm{BaO} & \begin{array}{l}
0.36 \mathrm{Al}_{2} \mathrm{O}_{3} \cdot 3.25 \\
0.17 \mathrm{MgO}
\end{array} \\
\mathrm{SiO}_{2} \cdot 0.20 \mathrm{~B}_{2} \mathrm{O}_{3}
\end{array}
\end{aligned}
$$

\section{5 秦地特性}

低火度焼成素地（K 素地）の特性について検討を加 えた。対照素地として市販磁器素地 ${ }^{13 i}(\mathrm{~J})$ を用いて比 較した。

\subsection{1 粒度分布}

本実験では粒度の違いによる可塑性や焼結の影響をな くすため上石坏土にほぼ近い粒度分布となるよう素地を 調製した，K 素地，上石素地の粒度分布を図 5 に示す。

\subsection{2 乾燥特性, 可塑性試験}

Bigot の方法 ${ }^{(6)} に よ り$ 坏土の乾燥収縮性を，また塑 性・液性限界試験，Pfefferkorn 試験により坏土の可塑 性について検討した。塑性・液性限界試験はJIS A 1205，1206により，Pfefferkorn 試験は常法により測定 した。結果を図6，図7，表 10 に示す.

乾燥収縮は上石坏土に比べ $\mathrm{K}$ 素地の方が $1.4 \%$ ほよ゙ 大きい，屈曲点である収縮限界水分も $\mathrm{K}$ 素地の方が高 い。表 10 のLL，PL は液性限界値，塑性限界值，PI は両者の差, LL + PL/2 はAtterberg の可塑性值, W はPfefferkorn の可塑性値である．K 素地は LL + PL/2 で $1.6 \%, W$ で $1.7 \%$ 高い水分值を示し同一変形量を得 るのに多くの水分を必要とする．乾燥特性や塑性限界水 分も高い值を示すことから $\overline{\mathrm{K}}$ 素地坏土は市販坏土水分

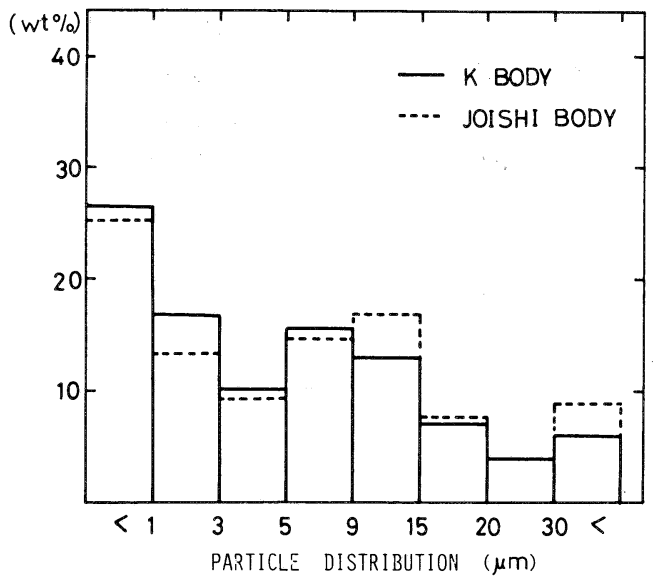

Fig. 5. Particles size distribution of $\mathrm{K}$ body and Joishi body.

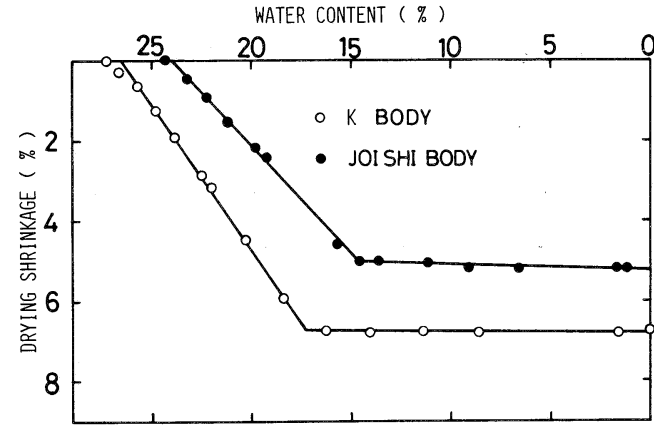

Fig.6. Drying shrinkage curve of green bodies.

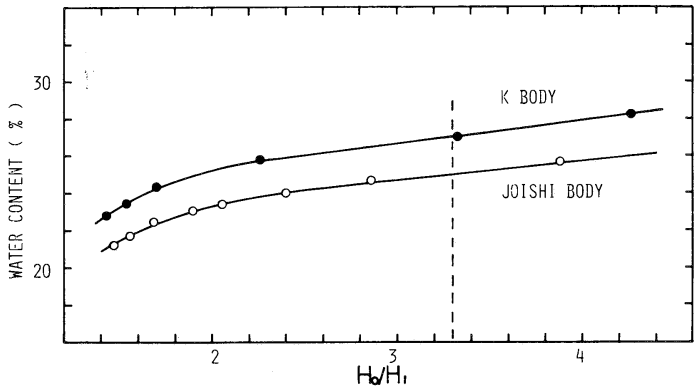

Fig. 7. Relation between water content and deformation ratio measured by the Pfefferkorn method.

Table 10. Plastic limit (PL), fluidity limit (LL) and Pfefferkorn test $(\mathrm{W})$.

\begin{tabular}{rccccc}
\hline & LL & PL & PI & LL+PL/2 & W \\
\hline K Body & 33.7 & 21.6 & 12.1 & 27.7 & 27.5 \\
JOISHI & 32.5 & 19.7 & 12.8 & 26.1 & 25.8 \\
Body & & & & & \\
\hline
\end{tabular}

より $2 \%$ 程度多くする必要がある.

\subsection{3 曲げ強さ, 衝撃強さ, 熱膨張}

曲げ強さ，衝撃強さ測定用試料は前述したものを 300 $\mathrm{kg} / \mathrm{cm}^{2}$ で加圧成形し $1.4 \times 7.5 \times 0.7 \mathrm{~cm}$ の角柱状とし た. 曲げ強さは 3 点曲げ法によりスパン $40 \mathrm{~mm}$, クロ スヘッド速度 $0.5 \mathrm{~mm} / \mathrm{min}$ で測定した. 衝撃強さはシャ ルピー衝撃試験機を用い測定した。結果を表 11 に示す. 曲げ強さは上石素地の $900 \mathrm{~kg} / \mathrm{cm}^{2}$ には及ばないものの $1115^{\circ} \mathrm{C}$ 焼成で $800 \mathrm{~kg} / \mathrm{cm}^{2}$ となる.

また焼成素地及び釉薬の熱膨張測定を行った，測定は 熱機械測定装置により荷重 $28 \mathrm{~g} / \mathrm{cm}^{2}$, 加熱速度 $15^{\circ} \mathrm{C} / \mathrm{min}$ で行った. 試料は $\mathrm{K}$ 素地は $1130^{\circ} \mathrm{C}$ 焼成物, 上石素地は $1260^{\circ} \mathrm{C}$ 焼成物を, 釉薬は( 3 )式低火度釉, 市販 1 号石灰釉を溶融後円柱状に切り出したものを用い 
Table 11. Bending strength and Charpy impact strength of firing bodies.

\begin{tabular}{ll}
$\begin{array}{r}\text { Bending Strength } \\
\left(\mathrm{kg} / \mathrm{cm}^{2}\right)\end{array}$ & $\begin{array}{c}\text { Impact Strength } \\
\left(\mathrm{kg} \cdot \mathrm{m} / \mathrm{cm}^{2}\right)\end{array}$ \\
\hline $\mathrm{K}$ Body & \\
$1115^{\circ} \mathrm{C} \quad 800$ & $0.97 \times 10^{-2}$ \\
$11300^{\circ} \mathrm{C} \quad 760$ & 1.35 \\
$1150^{\circ} \mathrm{C} \quad 720$ & 1.20 \\
$\mathrm{JOISHI}$ Body & \\
$1230^{\circ} \mathrm{C} \quad 900$ & 1.38 \\
$12600^{\circ} \mathrm{C} \quad 860$ & 1.41 \\
\hline
\end{tabular}

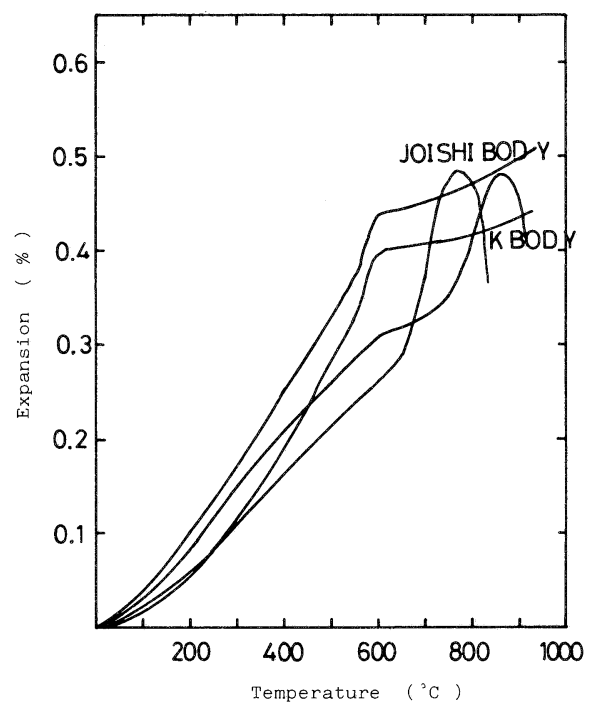

Fig. 8. Thermal expansion of firing bodies and glazes.

た. 測定結果を図 8 に示す.

上石素地の方が $\mathrm{K}$ 素地に比べやや膨張が大きいが, これは残留石英量の差によると思われる. 素地と釉との 適合性において上石素地, 1 号石灰釉では釉の膨張は素 地より小さく貫入はなく安定している。K 素地と低火 度釉では釉の膨張は素地より大きく貫入が発生しやすい 要因を残すが製品には貫入の発生は認められない.

\section{6 還元焼成 $\left(0.5 \mathrm{~m}^{3}\right.$ 都市ガス実験炉)}

ガス窯による還元焼成について検討した，炉内雾囲気 は連続式ガス分析装置 (赤外式 $\mathrm{CO}-\mathrm{CO}_{2}$ 計, 磁気式 $\mathrm{O}_{2}$ 計）を用いた。

酸化焼成域では従来と同様の焼成条件 ${ }^{17}$ である. 上石 素地に比べ素地・釉薬とも焼成温度が低く, 焼成幅も狭 いため還元焼成の開始時間, 還元濃度は注意を要する. 還元雾囲気は従来より低い $830^{\circ} \mathrm{C}$ からかけ始め $\mathrm{CO}$ ガ 又濃度も最高 $3 \%$ とした。釉薬はフリットが多く低い 温度でガラス化し始め煙をまきこみやすいため $1000^{\circ} \mathrm{C}$ 以上ではごく薄い雾囲気にする必要がある. 火止め温度 は $1100^{\circ} \mathrm{C}$, ゼーゲル錐 (京工試錐) SK 3 a で素地釉薬
とも良好である。

この低火度磁器は上石素地の焼成温度 SK 12 から SK $3 \mathrm{a}$ まで下げることができ, また焼成時間も数時間短縮 できることで然料消費量は 35〜 40\% 節減できた.

\section{7 鋳込み試験}

鋳込み成形の可能性について検討した。素地懸濁液の

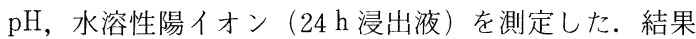
を表 12 に示す。

Table 12. $\mathrm{pH}$ and soluble cation concentration of body slip.

\begin{tabular}{lrrrrr}
\hline & pH & \multicolumn{3}{c}{ Soluble Cation } \\
& & $\mathrm{Na}^{+}$ & $\mathrm{K}^{+}$ & $\mathrm{Mg}^{++}$ & $\begin{array}{c}\text { (meog) } \\
\mathrm{Ca}^{++}\end{array}$ \\
\hline K Body & 9.4 & 10.45 & 0.73 & 0.17 & 1.32 \\
JoISHI & 7.2 & 0.43 & 0.26 & 0.08 & tr \\
\hline
\end{tabular}

$\mathrm{K}$ 素地はフリット，アルカリ，アルカリ土類成分を 添加しているため水溶性陽イオン, 特に $\mathrm{Na}^{+}, \mathrm{Ca}^{2+}$ イ オンの溶出が著しく $\mathrm{pH}$ も高くなっており，従来のケイ 酸ソーダでは良好な泥漿とはならない。他の解膠剤につ いて検討した結果，へキサメタリン酸ソーダ $0.05 \%+$ フミン酸ソーダ $0.06 \%$ 又はへキサメタリン酸ソーダ

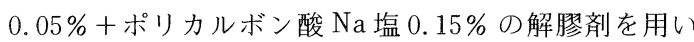
れば鋳込みにおける作業性は良好である。

\section{4. 総括}

現在の磁器素地の焼成温度より約 $150^{\circ} \mathrm{C}$ 低い $1120^{\circ} \mathrm{C}$ 前後で磁器化する新しい低火度焼成磁器素地の開発を行 いその磁器化過程, 素地特性を明らかにすることができ た。

1) $1100^{\circ} \mathrm{C}$ 程度で磁器化させるには融剤を必要とし $\mathrm{B}_{2} \mathrm{O}_{3}$ 系フリットは融剤としての効果は大きい.

2）石灰成分が多いとアノ一サイトが生成しムライト は認められない。アルカリ成分がある程度存在し，そこ へ石灰成分が導入されると残留石英の減少が著しく, 液 相が急激に生成し安定した磁器化状態を保つことは困難 となる。アルカリ， $\mathrm{CaO}$ 成分を少なくし，融液中で安 定なムライトを生成させることで焼成幅の広い素地を得 ることができる。

$$
\text { 3) } \left.\begin{array}{l}
0.40 \mathrm{KNaO} \\
0.16 \mathrm{CaO} \\
0.21 \mathrm{MgO}
\end{array}\right\} 1.00 \mathrm{Al}_{2} \mathrm{O}_{3} \cdot 6.99 \mathrm{SiO}_{2} \cdot 0.10 \mathrm{~B}_{2} \mathrm{O}_{3}
$$

この組成の素地は磁器化温度 $1115^{\circ} \mathrm{C}$ で焼成幅もあ る。

この素地は陶石合わせであるため可塑性もあり従来の生 産工程を変更することなく製造することが可能である.

4)この素地の乾燥収縮率は市販磁器坏土に比べ $1.4 \%$ 大きい值を示す. また可塑性試験の結果坏土水分 は市販坏土より約 $2 \%$ ほど多い 25～26\% にする必要が 
ある。

5）焼成物曲げ強さは $800 \mathrm{~kg} / \mathrm{cm}^{2}$ の值を示す.

6）還元焼成について適切な方法を見いだすことがで き,下絵付け呉須の発色も現在同様猻色ない結果を得た. 焼成に要する燃料は焼成温度を SK 3 a まで下げること により 35〜 40\% 節減することができる.

7）解膠剤にヘキサメタリン酸ソーダ，フミン酸ソー ダ, ポリカルボン酸 $\mathrm{Na}$ 塩を併用することにより鋳込み 成形が可能である.

謝 辞 本研究を行うに当たり多大な御指導を頂いた京都工 芸繊維大学 無機材料工学科・若松 盈教授及び名古屋工業技 術試験所第 6 部・金岡繁人博士に感謝の意を表します。また本 研究は中小企業庁昭和 56 年度技術開発研究費補助事業の援助に よったものであり，ここに謝意を表します。

\section{文献}

1) A. C. Bull, Trans. J. Brit. Ceram. Soc., 81, 69-74
(1982)

2) M. G. Naidis, Steklo i Keram,11,14-15 (1979)

3) 水田博之, 森田四郎, 第 25 回名工試研究発表予稿集, 26-28 (1978)

4）久井一也，公開特許公報，昭和 55-113662.

5) S. Lyng and K. Gamlem, Trans. J. Brit. Ceram. Soc., 73, 133-37 (1974)

6) D. Taylor, Trans. J. Brit. Ceram. Soc., 78, 108 (1979).

7）大串邦男, 関 秀哉, 昭和 54 年度技術開発成果普及講習 会テキスト (中小企業庁) 23 .

8）小南先吾, 伊藤 誠, ibid., 5 .

9) A. W. Norris and D. Taylor, Trans. J. Brit. Ceram. Soc., 78, 102-08 (1979).

10) L. A. Belostotskaya, Steklo, Keram. 10,15-16 (1979).

11) A. Ducarre, Interceram, 23, 64 (1974).

12) H. G. Wuhrer, Interceram, 20, 119 (1971).

13）今井寛治, 磯松良純, 京工試研究報告, 6, 79-84 (1977).

14）今井寛治，未発表.

15）川村資三，黒川利一，嘿協，88,703-12 (1980).

16) H. Schimdt, Sprechsaal, 113, 125 (1980).

17）今井寛治, 浅見 薫, 京工試研究報告, 8，56-62 (1977). 